\title{
Hyperkaliémie sévère
}

\section{Severe hyperkalemia}

\section{O. Peyrony $\cdot$ A. Elezi $\cdot$ P. Taboulet}

Reçu le 10 juillet 2013; accepté le 17 juillet 2013

(C) SFMU et Springer-Verlag France 2013

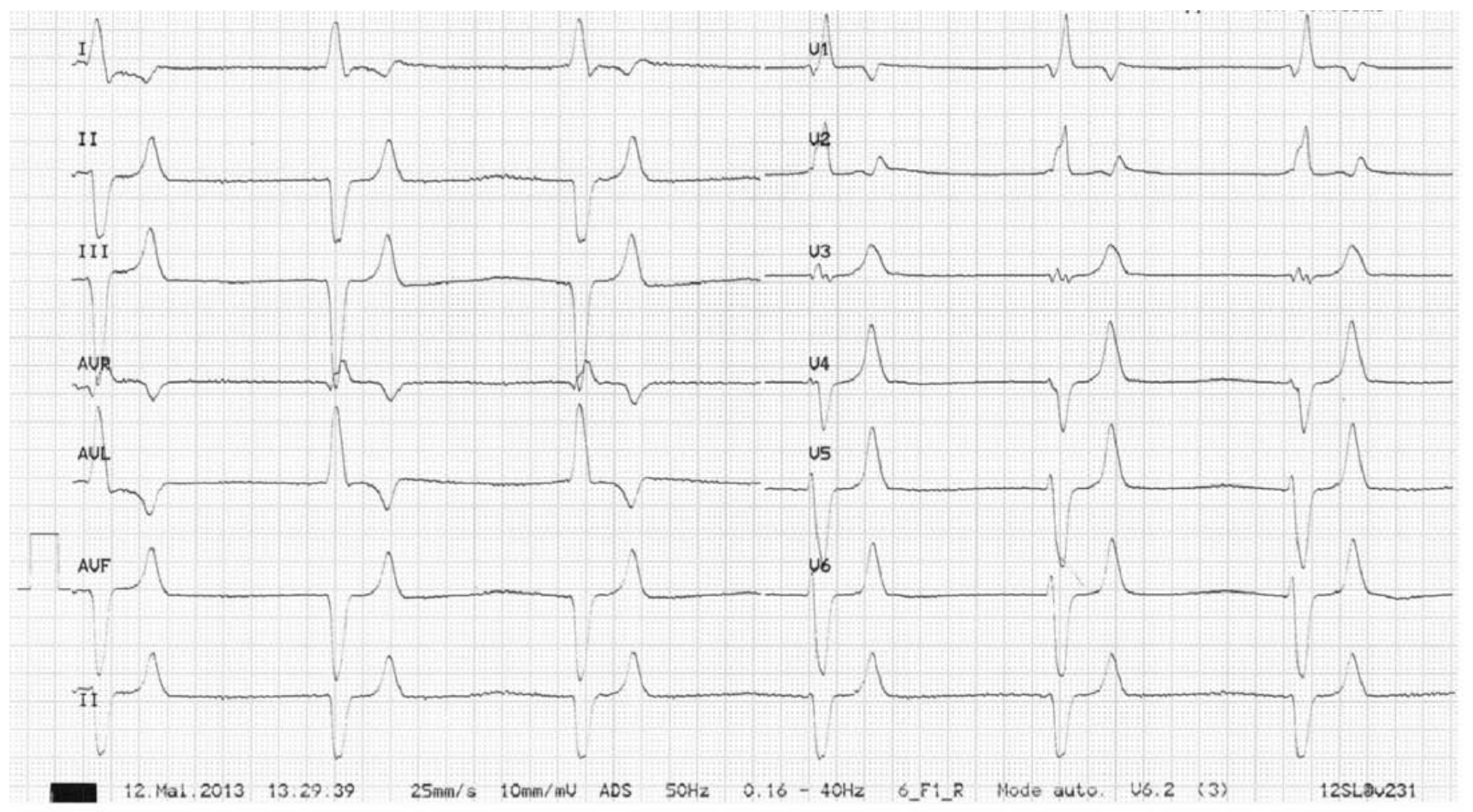

Fig. 1 ECG typique d'hyperkaliémie sévère

Un patient de 68 ans, diabétique, insuffisant rénal et hypertendu traité par inhibiteur calcique, inhibiteur de l'enzyme de conversion et spironolactone se présente aux urgences pour douleur abdominale diffuse, diarrhée profuse et vomissements. L'ECG montre une paralysie sinusale (absence d'ondes $P$ ), un rythme d'échappement jonctionnel à $35 / \mathrm{min}$, des QRS élargis avec un aspect en «lame de sabre » et des grandes ondes T « en tente ", amples et pointues à base fine (Fig. 1). Il est typique d'une hyperkaliémie sévère menaçant le pronostic vital. Le traitement doit être débuté sans délai (bicarbonates, gluconate de calcium, insuline et épuration extra-rénale) sans attendre le résultat du dosage du potassium (dosé à $8,7 \mathrm{mmol} / \mathrm{L}$ ). L'ECG s'est complètement normalisé après la dialyse. 